\title{
Assessment of The Characteristics of Nurse Scheduling in Hospital Ward
}

\author{
Rosly Zunaedi $^{1 *}$, Soenarnatalina Melaniani ${ }^{1}$, Ahsan $^{2}$ \\ ${ }^{1}$ Universitas Airlangga, Indonesia \\ ${ }^{2}$ Fakultas Kedokteran, Universitas Brawijaya, Indonesia \\ *roslyzunaedi@gmail.com
}

\begin{abstract}
Good scheduling arrangements are needed to prevent physical, emotional and psychological exhaustion in nurses which will harm the performance of nurses in providing services to patients. This study aimed to see an assessment overview of the characteristics of nurse work schedule in the hospital ward. This study used a descriptive survey design. The population in this study were all nurses in the ward of Lavalette Hospital - Malang. The sampling technique used was simple random sampling. Data collection using a scheduling criteria questionnaire. Most of the respondents considered that the work scheduling criteria currently applied in the ward were in the sufficient category $(80.2 \%)$. The results obtained are that there is 2 sub-variable coverage (309) and quality (321) with a value less than the total average value (322.08). Schedule consistency parameter (320) on the stability sub variable $<$ average value (322.08). Time parameter (317) on sub variable cost <average value (322.08). The problems that arise in the scheduling of nurses in the ward of Lavalette Hospital - Malang based on scheduling characteristics are the suitability of the number and distribution of nurses, the quality of the schedule, the exchange of schedules between nurses, and time to prepare the schedule.
\end{abstract}

Keywords: Nurse, Scheduling Characteristics, Work schedule 


\section{STRADA Jurnal Ilmiah Kesehatan}

DOI: $10.30994 /$ sjik.v9i2.528

ISSN: 2252-3847 (print); 2614-350X (online)

Vol.9 No.2 November 2020 Page.1755-1762

\section{BACKGROUND}

Scheduling employees is still a problem in the service industry for example is in the hospital. The increase in the number of patients, the severity of the patient's illness, organization, absence and personal requests for holidays, and the qualifications of nurses are factors in the difficulty of preparing an appropriate schedule (Susandi \& Milana, 2015). Good preparation is needed in scheduling arrangements. This preparation is needed so that there is no physical, emotional, and psychological fatigue which later has a negative impact on the performance of nurses in providing services to patients. The number of days that a given shift works before switching to another shift, the lag between changes in shift rotation, and the distribution of holidays can have an impact on the health and productivity of individuals in the workplace (Clark et al., 2015). units with longer overtime shifts and more nurses working overtime with lower levels of collaboration (Ma \& Stimpfel, 2018). Understanding good nursing service scheduling becomes one of the tasks for nursing and hospital managers.

In general, the nursing service schedule in Indonesia is divided into three shifts, namely morning, afternoon, and evening. Nurses who work longer or overtime result in decreased quality of nursing care in patients, decreased patient safety abilities, and more unresolved tasks (Griffiths et al., 2014). The decline in performance usually occurs because nurses have to be on standby in the morning, evening, and night shifts consecutively, which results in a lack of sleep. Lack of sleep increases the error rate in humans. To avoid this, the hospital needs to make clear rules to help nurses work well in accordance with the existing rules and nurses have a pleasant experience in doing their work (Rhéaume \& Mullen, 2018). In addition, bad scheduling also affects nurses to carry out activities outside of work. Working on the day and night shifts make it difficult for nurses to socialize with the environment outside of their work (Jensen et al., 2018).

The issue of work scheduling has received attention over the past few years because it is based on the concept of small actions with large effects that maximize organizational profitability through exploiting the availability of workers and equipment in the best possible way (El Adoly et al., 2018). Optimizing nursing staff is one of the duties of a manager so that the nursing care process and inpatient services run well. Flexible work schedules will increase productivity, reduce absenteeism, increase commitment, and be better hiring (O’Neal, 2012). Developing a flexible work schedule can be the right solution to improve the quality of service to patients. However, this must be followed by an appropriate ratio between the number of nurses and the number of patients (Kortbeek et al., 2015). The quite high difference in the ratio between the number of nurses and the number of patients affects the workload felt by nurses. The use of software for office scheduling is also one of the innovations offered to solve the nursing service scheduling problem. The software usage is considered to be able to maximize the distribution of nurses, fairness in scheduling, and easy leave requests (Ang et al., 2018). Office scheduling in its policy must consider several aspects of scheduling characteristics, namely: coverage, quality, stability, flexibility, fairness, and cost (Warner, 1976). The number of personnel availabilities, schedule patterns, schedule certainty in one period, anticipation of schedule changes, load equality between nurses, time, effort, and costs that appear in the nursing office scheduling process is the indicators assessed in this study.

This study aims to see an overview of the scheduling applied in the hospital ward based on the scheduling characteristics that exist in theory. The results of this study are expected to provide an overview of the assessment of the characteristics of work schedule 


\section{STRADA Jurnal Ilmiah Kesehatan}

DOI: $10.30994 /$ sjik.v9i2.528

ISSN: 2252-3847 (print); 2614-350X (online)

Vol.9 No.2 November 2020 Page.1755-1762

in the ward and can be used as a basis and consideration to determine follow-up to the nursing office scheduling process according to existing conditions.

\section{METHODS}

The research method used is descriptive quantitative. The population in this study were all nurses in the hospital ward as many as 151 nurses. The sampling technique used was simple random sampling. The research sample was obtained as many as 106 respondents. Respondents were randomly selected according to the inclusion criteria: nurses working in adult and pediatric wards, and exclusion criteria: nurses who worked in outpatient clinics, emergency departments, intensive care units, hemodialysis, and operating rooms and nurses with internship status.

The questionnaire used is a development of the scheduling characteristics theory put forward by D. Michael Warner (1976) which consists of 6 characteristics, including coverage, quality, stability, flexibility, fairness, and cost. The questionnaire consists of 26 statements which are closed statements with 4 (four) choices of answers "strongly agree" worth 4, "agree" has a value of 3 , "disagree" is worth 2 , and "disagree" is worth 1 . The results of the validity test of 26 statements obtained the results of the calculated $r$ value $>r$ table (0.3739). The results of the reliability test obtained an alpha value of 0.912 , which means that the characteristic instrument of work scheduling of nurses in the hospital ward is considered very reliable.

\section{RESULT}

Table 1. Characteristics of Work Scheduling in The Hospital Ward

\begin{tabular}{lcc}
\hline \multicolumn{1}{c}{ Category } & $\mathrm{f}$ & $\mathbf{( \% )}$ \\
\hline Good & 21 & 19.8 \\
Enough & 85 & 80.2 \\
\hline Total & 106 & 100.0 \\
\hline
\end{tabular}

Table 1 shows that most of the respondents rated the characteristics of work scheduling currently applied in hospital ward in the moderate category $(80.2 \%)$. 


\section{STRADA Jurnal Ilmiah Kesehatan}

DOI: $10.30994 /$ sjik.v9i2.528

ISSN: 2252-3847 (print); 2614-350X (online)

Vol.9 No.2 November 2020 Page.1755-1762

Table 2. The Results of Assessment of Sub Variable Characteristics of Nurse Scheduling in The Hospital Ward

\begin{tabular}{|c|c|c|c|c|c|}
\hline No. & $\begin{array}{l}\text { Sub Variable } \\
\text { Scheduling } \\
\text { Characteristics }\end{array}$ & Parameter & $\begin{array}{l}\text { The average } \\
\text { value of the } \\
\text { parameters }\end{array}$ & $\begin{array}{l}\text { The average } \\
\text { value of the sub } \\
\text { variables }\end{array}$ & $\begin{array}{l}\text { Average } \\
\text { value } \\
\text { (total) }\end{array}$ \\
\hline 1 & Coverage & $\begin{array}{l}\text { 1. Number of nurses } \\
\text { 2. Nurse's clinical } \\
\text { competence / } \\
\text { qualification }\end{array}$ & $\begin{array}{c}308.5 \\
309.67\end{array}$ & 309.1 & \multirow{6}{*}{322.08} \\
\hline 2 & Quality & $\begin{array}{l}\text { 1. Distribution of } \\
\text { working days and } \\
\text { off } \\
\text { 2. Work rotation }\end{array}$ & 317 & 321 & \\
\hline 3 & Stability & $\begin{array}{l}\text { 1. Schedule } \\
\text { consistency } \\
\text { 2. Duty cycle }\end{array}$ & $\begin{array}{c}320 \\
327.5\end{array}$ & 323.7 & \\
\hline 4 & Flexibility & $\begin{array}{l}\text { 1. Special request } \\
\text { 2. Change schedule }\end{array}$ & $\begin{array}{c}332.3 \\
325\end{array}$ & 328.6 & \\
\hline 5 & Fairness & $\begin{array}{l}\text { 1. Workload } \\
\text { distribution } \\
\text { 2. Clarity of tasks } \\
\text { 3. Number of days off }\end{array}$ & $\begin{array}{l}322 \\
328 \\
322\end{array}$ & 324 & \\
\hline 6 & Cost & $\begin{array}{l}\text { 1. Time } \\
\text { 2. Effort } \\
\text { 3. Costs }\end{array}$ & $\begin{array}{c}317 \\
326.5 \\
333.5\end{array}$ & 325.7 & \\
\hline
\end{tabular}

Table 2 shows the results of quantitative data about the characteristics of work schedule in the hospital ward. The results obtained are that there is 2 sub-variable coverage (309) and quality (321) with a value less than the total average value (322.08). Schedule consistency parameter (320) on the stability sub variable <average value (322.08). Time parameter (317) on sub variable cost $<$ average value (322.08).

\section{DISCUSSION}

The problem of scheduling has received attention over the past few years because it is based on the concept of small actions with large effects that maximize organizational profitability through exploiting the availability of workers and equipment in the best possible way (El Adoly et al., 2018). The results of the assessment of the characteristics of work scheduling in the hospital ward of Lavalette Hospital are mostly "sufficient". The assessment of scheduling characteristics is based on the suitability of the number and needs of nurses in the hospital ward (coverage). Scheduling is the arrangement and allocation of available time for nurses to carry out planned tasks to minimize costs and equalize workloads (Lin et al., 2015). The ability to determine the "right" number of staff, both to be hired and assigned to a particular shift, is important from a maintenance quality and efficiency perspective (Saville et al., 2019). The insufficient number of nurses has an impact on the nursing care process provided to patients (Griffiths et al., 2018). The impact that appears has been identified as causing harm to the patient (Recio-Saucedo et al., 2018). The insufficient number of nurses will cause the workload of nurses to increase so that nurses no longer carry out actions according to the competence of nurses. The insufficient number of personnel is not justified in doing long service because it will have an impact on care and can increase the potential for errors by nurses. Besides, the composition of nurses in terms of competence must be different so that the head nurse must pay attention to the competence and skill mix 


\section{STRADA Jurnal Ilmiah Kesehatan}

DOI: $10.30994 /$ sjik.v9i2.528

ISSN: 2252-3847 (print); 2614-350X (online)

Vol.9 No.2 November 2020 Page.1755-1762

of staff in the room (Rizany et al., 2017). Nursing services are carried out by providing nursing care to the community by the rules of the nursing profession by paying attention to the competencies that are under the nurse's career path (Kuokkanen et al., 2016). A higher level of competence in nurses has a positive impact on patient care outcomes and the mortality rate is shown to be lower, that is, patients are treated with optimal level distribution of nurses. Competency-based service schedules are more effective and facilitate work within the service schedule. However, the lack of manpower in terms of the number and equal distribution of competence in the unit and the ego of the nurse's person is an obstacle in compiling competency-based service schedules (Rahman et al., 2018)(Rizany et al., 2017).

Sub variable quality (quality) from the results of the study is also one of the problems that arise in the scheduling process in the hospital ward. Included in the quality points are holidays on weekends, single or separate holidays, and certain work rotation patterns as well as the demand for holidays at certain periods (Warner, 1976). A good service rotation pattern with proper shift and holiday schedule arrangements can allow nurses to be able to rest optimally so as not to appear fatigue and work fatigue. Nurses with acute and chronic fatigue feel poor physical performance. Nurses who report chronic fatigue feel they are less alert and less able to concentrate when providing patient care. Ineffective communication has also been linked to acute and chronic fatigue. In conclusion, fatigue has safety implications for nursing practice that must be monitored by nursing management (Sagherian et al., 2017).

Assessment of the stability sub variable (stability) obtained the lowest value on schedule consistency. In the process, there are often exchanges of schedules between nurses which results in differences in the workload of each nurse. Changing the schedule of nurses that is not appropriate is considered to have the potential to have negative consequences if in an emergency, the patient deteriorates and the morale of staff decreases (Clark et al., 2015). The shift that has the highest level of fatigue based on the results of the questionnaire is the morning shift. While the measurement results using the Bourdon Wiersma method, the results for the level of speed, level of accuracy and level of constancy can be concluded that the highest level of fatigue is in the afternoon shift. Based on the results of calculations of energy consumption and oxygen consumption using work physiology methods, the highest is in the morning and evening shifts (Juniar et al., 2017). Service scheduling that should have been determined is expected not to be able to change, this can affect the rotation of the office schedule which results in not optimal service.

The results of the nurse's assessment of the flexibility sub variable get the highest average value among other sub variables. This is due to the high level of work flexibility, the flexibility to change schedules and apply for holidays at certain times. For nurses, 'flexible work' means a tolerable work-life balance (Drake, 2019). Workforce flexibility is considered as a powerful concept in reducing the number of workers required and increasing job satisfaction. To adequately respond to the variability of patient demand, different types of flexibility are suggested, including the use of part-time employees, overtime and others (Kortbeek et al., 2015). Efforts to improve the work environment should be made through strategies such as greater flexibility of shift work, regular breaks during shifts, special places for quiet rest periods and providing an understanding of healthy sleep practices (Rhéaume $\&$ Mullen, 2018). However, providing a high leeway on the work schedule will put the quality of service at risk (Griffiths et al., 2014). The term 'flexibility' often has different meanings for employers and employees. For employers, flexibility is the capacity of the workforce to respond quickly to changes in service demand; for employees, it is scheduling designed to give them more control over when, where, or how they work (Drake, 2019). 


\section{STRADA Jurnal Ilmiah Kesehatan}

DOI: $10.30994 /$ sjik.v9i2.528

ISSN: 2252-3847 (print); 2614-350X (online)

Vol.9 No.2 November 2020 Page.1755-1762

The fairness sub-variable obtained a value above average, this is because the nurse considered that the division of work hours, clarity of division of tasks, and number of days off were deemed appropriate. In recent years, the aspect of fairness has been increasingly taken into account in the solution approach to nurse scheduling and rescheduling. However, definitions of justice vary widely. In principle, justice is translated as a sharing of the individual burdens received by each nurse (Stolletz \& Brunner, 2012). Justice can mean 'equality' (equality of results), 'worthiness' (individual freedom) or 'need' (social justice). Fairness in work scheduling is defined as equality of results. For example, the need for a 'fair' allocation of demand, annual leave, flexible work and study leave (Drake, 2019).

The cost sub-variable is defined as the amount of resources consumed for scheduling and operational scheduling including the time and effort required in preparing the schedule, as well as the costs incurred by the hospital for operational salaries and compensation for nurse overtime according to schedule. The time for scheduling is quite long also appears as one of the problems that arise in scheduling in the hospital ward. Several studies have shown that the use of information technology can increase the effectiveness and efficiency of work for both nurse managers and nurses.

A good understanding of shift work including fatigue identify, avoid and interventions that can address the problem of fatigue arising from scheduling effect is required by the nursing manager or those responsible for the scheduling (Haldar \& Sahu, 2015). The ability of each nurse to maximize the quality of the rest can also be one of the factors that can affect the effect of scheduling. It needs a proper guidance about the importance of proper time management, both from managers and nurses itself (Angouw et al., 2016). The electronic scheduling program has been shown to save time for senior staff, providing accurate and timely access to all nursing staff, fairness, equality of work shift patterns and easy leave management (Price, 2016). Electronic scheduling (e-rostering) is increasingly seen as a solution to the problem of scheduling work to be cost-effective, safe, fair (Snow, 2012).

\section{CONCLUSION}

Problems that arise in the scheduling of nurses in the hospital ward of Lavalette Hospital - Malang based on scheduling characteristics are the suitability of the number and distribution of nurses, the quality of the schedule, the exchange of schedules between nurses so that the schedule changes for each nurse, as well as the long schedule for compiling.

\section{REFFERANCE}

Ang, B. Y., Lam, S. W. S., Pasupathy, Y., \& Ong, M. E. H. (2018). Nurse workforce scheduling in the emergency department: A sequential decision support system considering multiple objectives. Journal of Nursing Management, 26(4), 432-441. https://doi.org/10.1111/jonm. 12560

Angouw, T. A., Josephus, J., Engkeng, S., Kesehatan, F., Universitas, M., \& Manado, S. R. (2016). Perbedaan Tingkat Kelelahan Kerja pada Perawat Shift Kerja Pagi, Shift Kerja Sore, dan Shift Kerja Malam di Ruangan Rawat Inap RSU GMIM Bethesda Tomohon. In PHARMACONJurnal Ilmiah Farmasi-UNSRAT (Vol. 5, Issue 2).

Clark, A., Moule, P., Topping, A., \& Serpell, M. (2015). Rescheduling nursing shifts: Scoping the challenge and examining the potential of mathematical model based tools. Journal of Nursing Management, 23(4), 411-420. https://doi.org/10.1111/jonm.12158

Drake, R. (2019). Dilemmas of e-rostering old and new: towards intelligent systems? Nursing

Times,

$115(6)$,

$19-23$. 


\section{STRADA Jurnal Ilmiah Kesehatan}

DOI: $10.30994 /$ sjik.v9i2.528

ISSN: 2252-3847 (print); 2614-350X (online)

Vol.9 No.2 November 2020 Page.1755-1762

http://search.ebscohost.com/login.aspx?direct=true \&db=cin20\&AN=138669888\&site $=$ ehost-live

El Adoly, A. A., Gheith, M., \& Nashat Fors, M. (2018). A new formulation and solution for the nurse scheduling problem: A case study in Egypt. Alexandria Engineering Journal, 57(4), 2289-2298. https://doi.org/10.1016/j.aej.2017.09.007

Griffiths, P., Dall'Ora, C., Simon, M., Ball, J., Lindqvist, R., Rafferty, A.-M., Schoonhoven, L., Tishelman, C., \& Aiken, L. H. (2014). Nurses' Shift Length and Overtime Working in 12 European Countries. Medical Care, 52(11), 975-981. https://doi.org/10.1097/MLR.0000000000000233

Griffiths, P., Recio-Saucedo, A., Dall'Ora, C., Briggs, J., Maruotti, A., Meredith, P., Smith, G. B., \& Ball, J. (2018). The association between nurse staffing and omissions in nursing care: A systematic review. In Journal of Advanced Nursing (Vol. 74, Issue 7). https://doi.org/10.1111/jan.13564

Haldar, P., \& Sahu, S. (2015). Occupational stress and work efficiency of nursing staff engaged in rotating shift work. Biological Rhythm Research, 46(4), 511-522. https://doi.org/10.1080/09291016.2015.1021153

Jensen, H. I., Larsen, J. W., \& Thomsen, T. D. (2018). The impact of shift work on intensive care nurses' lives outside work: A cross-sectional study. Journal of Clinical Nursing, 27(3-4), e703-e709. https://doi.org/10.1111/jocn.14197

Juniar, H. H., Astuti, R. D., \& Iftadi, I. (2017). Analisis Sistem Kerja Shift Terhadap Tingkat Kelelahan dan Pengukuran Beban Kerja Fisik Perawat RSUD Karanganyar. PERFORMA : Media Ilmiah Teknik Industri, 16(1), 44-53. https://doi.org/10.20961/performa.16.1.12750

Kortbeek, N., Braaksma, A., Burger, C. A. J., Bakker, P. J. M., \& Boucherie, R. J. (2015). Flexible nurse staffing based on hourly bed census predictions. International Journal of Production Economics, 161, 167-180. https://doi.org/10.1016/j.ijpe.2014.12.007

Kuokkanen, L., Leino-Kilpi, H., Numminen, O., Isoaho, H., Flinkman, M., \& Meretoja, R. (2016). Newly graduated nurses' empowerment regarding professional competence and other work-related factors. BMC Nursing, 15(1), 1-8. https://doi.org/10.1186/s12912-016-0143-9

Lin, P.-C., Chen, C.-H., Pan, S.-M., Chen, Y.-M., Pan, C.-H., Hung, H.-C., \& Wu, M.-T. (2015). The association between rotating shift work and increased occupational stress in nurses. Journal of Occupational Health, 57(4), 307-315. https://doi.org/10.1539/joh.13-0284-OA

Ma, C., \& Stimpfel, A. W. (2018). The association between nurse shift patterns and nursenurse and nurse-physician collaboration in acute care hospital units. Journal of Nursing Administration, 48(6), 335-341. https://doi.org/10.1097/NNA.0000000000000624

O'Neal, A. (2012). The effects of work schedule flexibility on job satisfaction of telephone advice nurses. 2012, 76. http://digitalcommons.kennesaw.edu/etd/535/

Rahman, S., Mulyani, Y., \& Rizany, I. (2018). Penjadwalan Dinas Perawat berhubungan dengan Kepuasan Pasien di Ruang Rawat Inap RSUD Ulin Banjarmasin. Dunia Keperawatan, 6(1), 41. https://doi.org/10.20527/dk.v6i1.5081

Recio-Saucedo, A., Dall'Ora, C., Maruotti, A., Ball, J., Briggs, J., Meredith, P., Kovacs, C., Prytherc, D., Smith, G. B., \& Griffiths, P. (2018). What impact does nursing care left undone have on patient outcomes? Review of the literature (Vol. 27). https://doi.org/10.1111/jocn.14058

Rhéaume, A., \& Mullen, J. (2018). The impact of long work hours and shift work on cognitive errors in nurses. Journal of Nursing Management, 26(1), 26-32. 


\section{STRADA Jurnal Ilmiah Kesehatan}

DOI: $10.30994 /$ sjik.v9i2.528

ISSN: 2252-3847 (print); 2614-350X (online)

Vol.9 No.2 November 2020 Page.1755-1762

https://doi.org/10.1111/jonm.12513

Rizany, I., Sri Hariyati, T., \& Purwaningsih, S. (2017). Optimalisasi Fungsi Kepala Ruangan Dalam Penetapan Jadwal Dinas Perawat Berbasis Kompetensi: Pilot Study. Jurnal Persatuan Perawat Nasional Indonesia (JPPNI), 1(3), 244. https://doi.org/10.32419/jppni.v1i3.35

Sagherian, K., Clinton, M. E., Abu-Saad Huijer, H., \& Geiger-Brown, J. (2017). Fatigue, Work Schedules, and Perceived Performance in Bedside Care Nurses. Workplace Health and Safety, 65(7), 304-312. https://doi.org/10.1177/2165079916665398

Saville, C. E., Griffiths, P., Ball, J. E., \& Monks, T. (2019). How many nurses do we need? A review and discussion of operational research techniques applied to nurse staffing. International Journal of Nursing Studies, 97, 7-13. https://doi.org/10.1016/j.ijnurstu.2019.04.015

Snow, T. (2012). concern over the knock-on effects of growing gaps in nursing roster. 26, $12-13$.

Stolletz, R., \& Brunner, J. O. (2012). Fair optimization of fortnightly physician schedules with flexible shifts. European Journal of Operational Research, 219(3), 622-629. https://doi.org/10.1016/j.ejor.2011.10.038

Susandi, D., \& Milana, L. (2015). Perancangan dan Pembuatan Aplikasi Penyusunan Jadwal Kerja Dinas Jaga Perawat IGD Menggunakan Algoritma TPB. In Jurnal Metris (Vol. 16).

Warner, D. M. (1976). Scheduling Nursing Personnel According to Nursing Preference: A Mathematical Programming Approach. Operations Research, 24(5), 842-856. https://doi.org/10.1287/opre.24.5.842 